\title{
Ocurrence of the sea anemone Telmatactis panamensis (Verrill, 1869) (Cnidaria: Anthozoa: Actiniaria) at Isla del Coco National Park, Costa Rica
}

\author{
Fabián H. Acuña ${ }^{1,2}$, Jorge Cortés ${ }^{3,4}$ \& Agustín Garese ${ }^{1,2}$ \\ 1. Instituto de Investigaciones Marinas y Costeras (IIMyC) - CONICET. Facultad de Ciencias Exactas y Naturales. \\ Universidad Nacional de Mar del Plata. Funes 3250. 7600 Mar del Plata. Argentina, fax: (223) 4753150; \\ facuna@mdp.edu.ar \\ 2. Consejo Nacional de Investigaciones Científicas y Técnicas (CONICET). \\ 3. Centro de Investigación en Ciencias del Mar y Limnología (CIMAR), Ciudad de la Investigación, Universidad de \\ Costa Rica, San Pedro, 11501-2060 San José, Costa Rica. \\ 4. Escuela de Biología, Universidad de Costa Rica, San Pedro, 11501-2060 San José, Costa Rica.
}

Received 30-VIII-2010. C Corrected 23-IV-2012. Accepted 24-IX-2012.

\begin{abstract}
The sea anemone fauna of Isla del Coco National Park (also known as Cocos Island Nacional Park), Pacific Costa Rica is poorly known. In the present work we report the first occurrence of the species Telmatactis panamensis. Individuals of this sea anemone $(\mathrm{n}=24)$ were collected at Chatham Bay intertidal and at $15 \mathrm{~m}$ depth in Punta Ulloa, in both cases attached to rocks; during the expedition UCR-UNA-COCO-I in April 2010. We provide photographs of live individuals, external anatomy and an inventory of cnidae of the studied specimens. Possibly this species is extended to greater depth as observed by other authors in the Galápagos Islands. Citation: Acuña, F.H., J. Cortés \& A. Garese. 2012. Ocurrence of the sea anemone Telmatactis panamensis (Verrill, 1869) (Cnidaria: Anthozoa: Actiniaria) at Isla del Coco National Park, Costa Rica. Rev. Biol. Trop. 60 (Suppl. 3): 201-205. Epub 2012 Dec 01.
\end{abstract}

Key words: Telmatactis panamensis, sea anemone, Actiniaria, Cocos Islands, Tropical Eastern Pacific, Isla del Coco, Costa Rica.

Cocos Island (Isla del Coco, Costa Rica) is one of the oceanic islands in the Eastern Tropical Pacific. The marine fauna of this island have been the subject of scientific interest especially for the biogeographic relevance and biodiversity (Breedy \& Cortés 2008). This island has been the target of numerous expeditions to explore the island's species richness (Cortés 2008); notwithstanding some groups like the sea anemone fauna are practically unknown. The only record of a sea anemone is the species Telmatactis cricoides (cited as T. americana) (Cortés 1996/1997), based on a photographic record (Bradley \& Ireland 1993), but its identification is doubtful. During the expedition UCR-UNA-COCO-I to Isla del Coco National Park in April 2010 we sampled many sites and collected many individuals of sea anemones, both from the intertidal and deeper zones. This sampling allowed us to identify the species T. Panamensis, this being the first record of a sea anemone based on collected individuals from this island.

\section{MATERIAL AND METHODS}

The individuals were collected by hand from the intertidal zone at Bahía Chatham

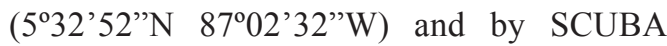
dives at Punta Ulloa (5 $5^{\circ} 33^{\prime} 05^{\prime \prime} \mathrm{N} 87^{\circ} 02^{\prime} 06^{\prime}$ 'W), Isla del Coco National Park, Costa Rica; during the expedition UCR-UNA-COCO-I in April 2010. Individuals were anesthetized by the addition of crystals of magnesium chloride, and preserved in 5\% formalin and later in 
ethanol $70 \%$. The external characters of live specimens were observed in the field and also in preserved material in the lab. The internal anatomy was studied by dissections under the stereoscopic microscope. The cnidae was analyzed using a Zeiss Axiolab Microscope with micrometric eyepiece at a magnification of 1000X (oil immersion). Terminology of cnidae follows England (1991). The current classification of sea anemones, synonymy and the taxonomic status were cross-checked with the electronic database "Hexacorallians of the World" (Fautin 2011).

\section{RESULTS}

Classification

Order Actiniaria

Suborder Nynantheae

Infraorder Thenaria

No Rank Acontiaria

Family Isophellidae

Genus Telmatactis

Telmatactis panamensis (Verrill, 1869)

\section{Synonymy}

Phellia Panmensis Verrill, 1869, p. 490 (original description).

Phellia panamensis Hertwig, 1882, p. 81.

Phelliopsis Panamensis Verrill, 1899, p. 214-216.

Phellia rapanuiensis Carlgren, 1922 (1920), p. 153-156.

Telmatactis panamensis Carlgren, 1949, P. 91. Telmatactis rapanuiensis Carlgren, 1949, p. 91.

\section{Characteristics of studied specimens}

In the intertidal zone of Bahía Chatham 24 small specimens were collected under rocks during low tides, while at Punta Ulloa six individuals under rocks were sampled at $15 \mathrm{~m}$ depth (Fig. 1) during two dives. After preservation most of them retracted their tentacles but remained the column extended. The column diameter varies between $0.3 \mathrm{~cm}$ and $2 \mathrm{~cm}$, and height from $0.4 \mathrm{~cm}$ to $2.3 \mathrm{~cm}$ in preserved state. Scapus wrinkled brown/orange, thick-walled

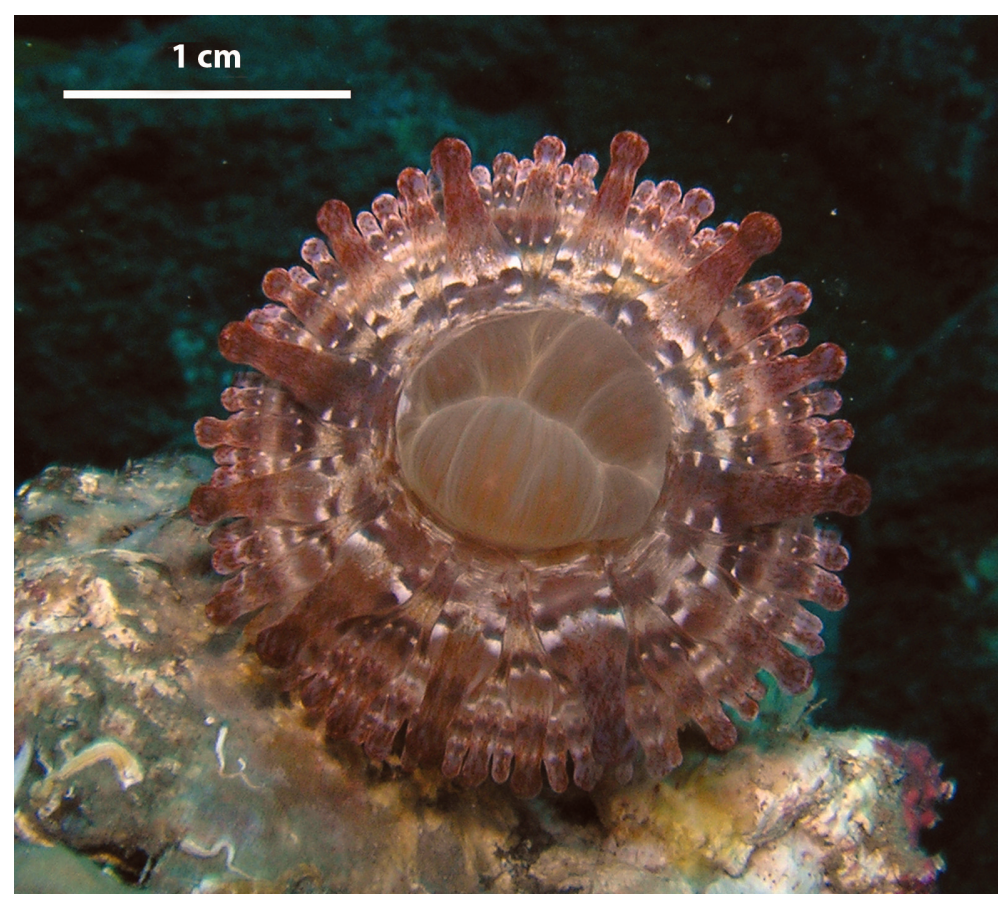

Fig. 1. Individual of Telmatactis panamensis from Punta Ulloa showing the oral disc and tentacles. Photograph by Jaime Nivia. 
scapulus (Fig. 2). Acontia may be emitted through scapus and was observed in some of the collected individuals (both live and preserved). Actinopharynx paler orange than column; two symmetrical siphonoglyphes, each have white marking at its intersection with oral disk. Oral disk tentacle-free in central zone. Digitiform tentacles reddish brown with a proximal white crossband and swollen at their end, internal longer than external. Tentacles from 44 to 79 . Those of the primary and secondary cycles much better developed than the others. In Table 1 the size and distribution of cnidae is detailed. The cnidom is composed by spirocysts, basitrichs, microbasic p-mastigophores and microbasic amastigophores.

\section{Distribution other than Isla del Coco National Park}

Galápagos Islands (Fautin et al. 2007), Chile: Easter Island (Rapanui) (Carlgren 1922), Mexico: Baja California (Carlgren 1951) and Panama (Verrill 1869).

\section{DISCUSSION}

The sea anemone $T$. panamensis is a new record for Isla del Coco National Park (Costa Rica). It is a common sea anemone in the intertidal of Bahía Chatham and Punta Ulloa at $15 \mathrm{~m}$ depth, usually attached under rocks, but can also be found attached to large cobbles or shells as was observed by Fautin et al. (2007) in specimens from the Galápagos Islands. Bradley \& Ireland (1993) in their photo guide illustrate an specimen of $T$. cricoides from Isla del Coco National Park (Cortés 1996/1997), but this record is based on a photo and no data are provided on its location, depth or anatomical characteristics, being therefore uncertain.

The anatomical characteristics of studied specimens from Isla del Coco National Park agree very well with the description of $T$. panamensis by Carlgren (1951) and Fautin et al. (2007), therefore we assigned the analyzed individuals to this species. Doumenc et al. (1989) in his work on variability of Telmatactis

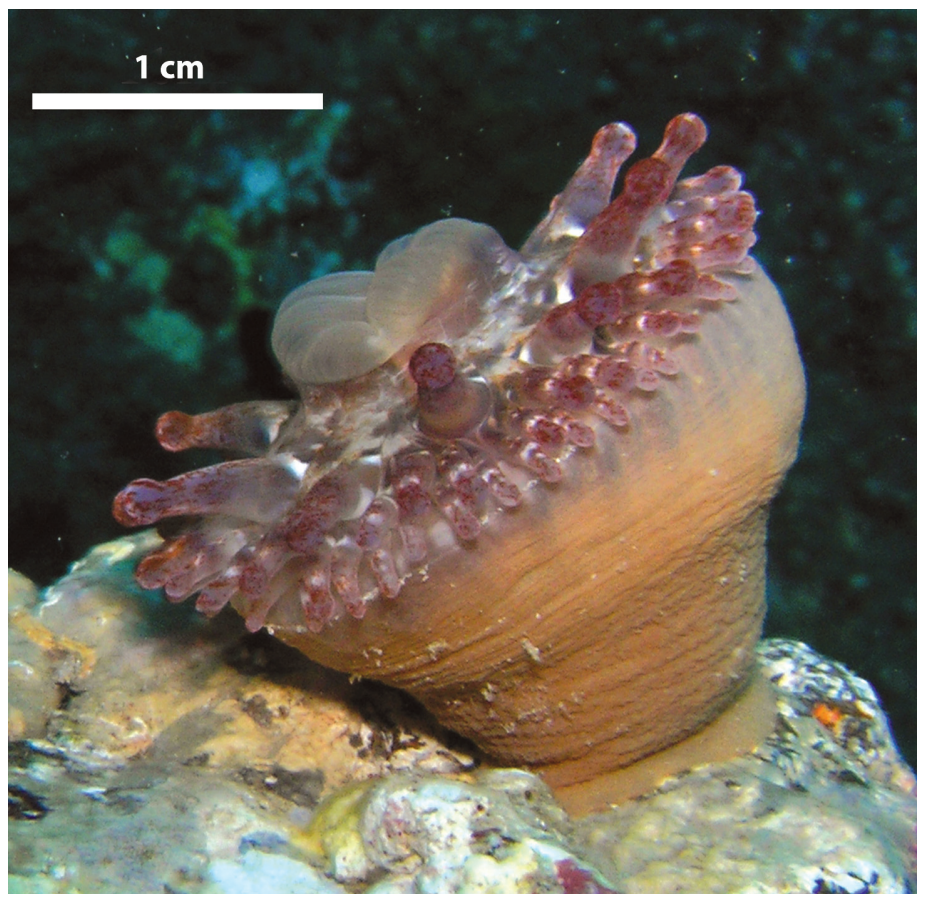

Fig. 2. Individual of Telmatactis panamensis from Punta Ulloa showing the wrinkled column. Photograph by Jaime Nivia. 
TABLE 1

Distribution and size of cnidae of Telmatactis panamensis

\begin{tabular}{|c|c|c|c|c|}
\hline Cnidae & $\begin{array}{l}\text { Range in } \mu \mathrm{m} \\
\text { Length }(\mathrm{mean} \pm \mathrm{sd}) \mathrm{x} \text { width (mean) }\end{array}$ & $\mathrm{n}$ & $\mathrm{N}$ & Abundance \\
\hline \multicolumn{5}{|l|}{ Tentacles } \\
\hline Spirocysts & $17-37(25.45 \pm 4.70) \times 2-6(3.42)$ & 73 & $4 / 4$ & ++++ \\
\hline Basitrichs & $33-57(45.09 \pm 6.82) \times 2-5(3.28)$ & 71 & $4 / 4$ & ++++ \\
\hline Microbasic p-mastigophores & $26-41(33.29 \pm 3.58) \times 4-6(4.96)$ & 27 & $4 / 4$ & + \\
\hline \multicolumn{5}{|l|}{ Actinopharynx } \\
\hline Basitrichs I & $21-35(26.46 \pm 3.20) \times 2-4(3.10)$ & 86 & $4 / 4$ & ++++ \\
\hline Basitrichs II & $12-19(15.03 \pm 2.19) \times 2-4(2.14)$ & 76 & $4 / 4$ & +++ \\
\hline Microbasic p-mastigophores & $37-60(49.11 \pm 4.58) \times 7-14(8.90)$ & 87 & $4 / 4$ & ++++ \\
\hline Microbasic p-mastigophores & $25-33(28.27 \pm 2.32) \times 4-7(5.50)$ & 11 & $3 / 4$ & + \\
\hline \multicolumn{5}{|l|}{ Mesenterial filaments } \\
\hline Basitrichs I & $35-56(48.03 \pm 5.55) \times 2-4(3.03)$ & 29 & $3 / 4$ & + \\
\hline Basitrichs II & $12-25(18.43 \pm 3.24) \times 2-5(2.26)$ & 83 & $4 / 4$ & ++++ \\
\hline Microbasic p-mastigophores & $41-66(53.58 \pm 6.98) \times 7-13(9.60)$ & 48 & $4 / 4$ & +++ \\
\hline Microbasic p-mastigophores & $12-20(15.49 \pm 1.52) \times 4-6(4.49)$ & 89 & $4 / 4$ & ++++ \\
\hline \multicolumn{5}{|l|}{ Acontia } \\
\hline Basitrichs II & $17-29(22.20 \pm 1.84) \times 2-3(2.42)$ & 89 & $4 / 4$ & ++++ \\
\hline Microbasic p-mastigophores & $46-63(55.57 \pm 3.85) \times 9-17(11.55)$ & 89 & $4 / 4$ & ++++ \\
\hline \multicolumn{5}{|l|}{ Column } \\
\hline Microbasic amastigophore & $13-17(15.12 \pm 0.92) \times 3-5(3.77)$ & 102 & $4 / 4$ & ++++ \\
\hline Basitrichs I & $40-56(45.2 \pm 7.42) \times 3-4(3.6)$ & 5 & $3 / 4$ & + \\
\hline Basitrichs II & $18-26(22.06 \pm 2.21) \times 2-3(2.24)$ & 47 & $4 / 4$ & ++ \\
\hline
\end{tabular}

$\mathrm{n}$ : total number of capsules measured.

$\mathrm{N}$ : proportion of animals studied that contained the cnida.

+rare, ++++ abundant.

provide a worldwide inventory of this speciesrich genus and conclude that most of species of Telmatactis are entirely littoral. However, Fautin et al. (2007) found that T. panamensis extends much deeper, while Wirtz (1996) mentioned a range of $0-62 \mathrm{~m}$ for $T$. cricoides; in this way it is probable that population of T. panamensis at Isla del Coco National Park may also extend deeper and also to other sites around the island, which may be verified in future expeditions.

\section{ACKNOWLEDGMENTS}

We are grateful to Jaime Nivia for the images of $T$. panamensis that illustrate this paper and to Rodrigo ('Yoyo') Roesch for helping us sampling. To Programa de Promoción de la Universidad Argentina (PPUA) and
CONICET for granting FHA to visit CIMAR (UCR) during 2009 and 2010. The expedition to Isla del Coco National Park was funded by the Consejo Nacional de Rectores de las Universidades Públicas (CONARE), with additional support by CIMAR and the Undersea Hunter Group.

\section{RESUMEN}

La fauna de anémonas de mar es prácticamente desconocida para el Parque Nacional Isla del Coco (Costa Rica). En el presente trabajo se reporta por primera vez la presencia de la especie Telmatactis panamensis. Individuos de esta anémona de mar fueron colectados en el intermareal de Bahía Chatham y a $15 \mathrm{~m}$ de profundidad en Punta Ulloa, en ambos casos adheridas a rocas; durante la expedición UCR-UNA-COCO-I en Abril de 2010. Se proveen fotografías de ejemplares vivos, datos de su anatomía externa y un inventario del cnidae de los especímenes 
estudiados. Posiblemente esta especie se extienda a mayor profundidad, tal como fue observado por otros autores para ejemplares de las Islas Galápagos.

Palabras clave: Telmatactis panamensis, anémona de mar, Actiniaria, Isla del Coco, Pacífico Tropical Este, Costa Rica.

\section{REFERENCES}

Bradley, G.E. \& J. Ireland. 1993. Such is Life in Costa Rica Underwater. Printex Int., San José, Costa Rica. 95 p.

Breedy, O. \& J. Cortés. 2008. Octocorals (Coelenterata: Anthozoa: Octocorallia). Rev. Biol. Trop. 56 (Suppl. 2): 71-77.

Carlgren, O. 1922. Actiniaria jund Zoantharia von Juan Fernandez und der Osterinsel: Pp. 145-160 (Chapter 20). In C. Skottsberg (Ed.). The Natural History of Juan Fernandez and Easter Island. Vol. 3. Almquist und Wiksells Boktryckeri, Uppsala.

Carlgren, O. 1951. The actiniarian fauna of the Gulf of California. Proc. U.S. Natl. Mus. 101: 415-449.

Cortés, J. 1996/1997. Biodiversidad marina de Costa Rica: Filo Cnidaria. Rev. Biol. Trop 44(3)/45(1): 323-334.

Cortés, J. 2008. Historia de la investigación marina de la Isla del Coco, Costa Rica. Rev. Biol. Trop. 56 (Supl.2): 1-18.
Doumenc, D., C. Chintiroglou \& A. Foubert. 1989. Variabilité du genre Telmatactis Gravier, 1918 (Actiniaria, Acontiaria, Isophellidae). Bull. Mus. Natl. Hist. Nat. ser. 4, 11(A): 5-45.

England, K.W. 1991. Nematocysts of sea anemones (Actiniaria, Ceriantharia and Corallimorpharia: Cnidaria): nomenclature, Pp. 691-697. In: R.B. Williams, P.F.S. Cornelius, R.G. Hughes \& E.A. Robson (Eds.). Coelenterate Biology: Recent Research on Cnidaria and Ctenophora. Kluewer, Dordrecht, The Netherlands.

Fautin, D.G. 2011. Hexacorallians of the World. http://geoportal.kgs.ku.edu/hexacoral/anemone2/index.cfm. Accessed in April 2012.

Fautin D.G, C.P. Hickman Jr., M. Daly \& T. Molodtsova. 2007. Shallow-water sea anemones (Cnidaria: Anthozoa: Actiniaria) and tube anemones (Cnidaria: Anthozoa: Ceriantharia) of the Galápagos Islands. Pac. Sci. 61: 549-573.

Verrill, A.E. 1869. Review of the polyp's of the west coast of America. Trans. Conn. Acad. Arts Sci. 1: 377-558.

Wirtz, P. 1996. The sea anemone Telmatactis cricoides from Madeira and the Canary Islands: Size, frequency, depth distribution and colour polymorphism. Arquipélago 14A: 1-5. 
